\title{
Ecological Restoration in Mexico: The Challenges of a Multicultural Megadiverse Country
}

\author{
Roberto Lindig-Cisneros
}

M exico, with a land mass of $1,964,375 \mathrm{~km}^{2}$, belongs to the group of megabiodiverse countries with more than 23,400 plant species (Sarukhán 2008). Within its boundaries lie tropical evergreen forests, deserts, and coastal and alpine ecosystems. This biological richness is matched by a cultural diversity that is the result of a long history of human occupation. In what is today central and southern Mexico, the vestiges of the main Mesoamerican civilizations can be found, from the sites of the ancient Olmec civilization in the Gulf of Mexico to Mayan, Aztec, and Tarascan sites, the three most advanced civilizations that the Spanish conquerors discovered more than 500 years ago in this region of the Americas. Even today, approximately 7.6 million of Mexico's inhabitants speak a native language. These languages can be grouped in 12 linguistic families (Díaz 2010). Among the ethnic groups, some have occupied their ancestral lands for centuries, creating landscapes that merge nature and culture.

High biodiversity in a multicultural country presents particularly difficult challenges for restoration. In many cases, for restoration to occur, careful consideration must be given not only to barriers to ecosystem recovery, but also to establishing a dialogue between cultures that typically share little in terms of their views on nature. Furthermore, as a consequence of the social struggle that occurred at the beginning of the 20th century that led to the Mexican Revolution, almost all the national territory was distributed among the population. Nowadays, 52\% of the Mexican territory is owned by ejidos, a type of communal land ownership system rooted in pre-Columbian social structures and rural communities. About $40 \%$ is private property, and only $8 \%$ is owned by the state (Rivera Rodríguez 2003).
Therefore, practically all restoration efforts in Mexico require working with landowners that depend directly on the land for subsistence, adding an additional layer of complexity to restoration. The need for ecological restoration in Mexico has been recognized at least since the end of the 19th century, when two botanical pioneers, Fernando Altamirano and José Ramírez, published a list of species useful for revegetating the forests of Mexico (Flores Olvera and Lindig-Cisneros 2005).

The number of restoration projects in Mexico has increased in recent decades, partly because of the efforts by the governmental Comisión Nacional para el Conocimiento y Uso de la Biodiversidad, which funds restoration efforts mostly in protected areas and priority conservation regions. These are areas of particular interest because of their high biodiversity and relative ecological integrity.

Elsewhere in the country, restoration has been accomplished primarily by local communities, mostly rural, in collaboration with NGOs and universities. The series of papers presented in this issue illustrate many of the challenges and approaches to ecological restoration in Mexico. Common to almost all of these articles is the preponderant role of social issues and the need for developing knowledge on topics as basic as the propagation of native species. An effort was made in this special issue to cover as much as possible of the ecosystem diversity and geography of Mexico, but in such a complex and diverse country of course much was left out. Although restoration is a growing field of endeavor in Mexico, considerable work still needs to be done to link research with practice and to strengthen a multicultural relationship with nature for its preservation and restoration. These articles help pave the way. 


\section{References}

Díaz, D. 2010. Los pueblos indios de México. Arqueología Mexicana 34:82-91.

Flores, H. and R. Lindig-Cisneros. 2005. La lista de árboles y arbustos propios para repoblar los bosques de la República Mexicana de Fernando Altamirano y José Ramírez a 110 años de su publicación. Revista Mexicana de Biodiversidad 76:11-35.

Rivera Rodríguez, I. 2003. Tenencia de la tierra y derechos agrarios. Report prepared for the Secretaría de Agricultura, Ganadería, Desarrollo Rural, Pesca y Alimentación, México. www.sagarpa.gob.mx/v1/desarrollorural/publicaciones/ memoria-eventos/seminario/1_eirr_sra.pdf

Sarukhán, J. 2008. Conocimiento Actual de la Biodiversidad. Vol. 1 of Capital Natural de México. Mexico City: Comisión Nacional para el Conocimiento y Uso de la Biodiversidad.
Roberto Lindig-Cisneros is a full-time researcher at the Centro de Investigaciones en Ecosistemas of the Universidad Nacional Autónoma de México. His research interests include the effects of restoring diversity on recovering ecosystem services and the interactions among native and invasive species under restoration conditions. He has worked for almost ten years with rural and indigenous communities in participatory research on restoration of severely degraded sites. He can be contacted at Laboratorio de Ecología de Restauración, Centro de Investigaciones en Ecosistemas, UNAM, Apartado Postal 27, Admón. 3, Santa María, 58091, Morelia, Michoacán, México, rlindig@oikos.unam.mx. 